Barbara Thériault

The Cop and the Sociologist

Culture and Social Practice 
Barbara Thériault is Associate Professor of Sociology and Director of the Canadian Centre for German and European Studies at the University of Montreal. She holds a PhD from the Max Weber Centre for Cultural and Social Studies (University of Erfurt, Germany). 
BARBARA THÉRIAULT

\section{The Cop and the Sociologist}

Investigating Diversity in German Police Forces

[transcript] 


\section{Bibliographic information published by the Deutsche Nationalbibliothek}

The Deutsche Nationalbibliothek lists this publication in the Deutsche Nationalbibliografie; detailed bibliographic data are available in the Internet at http://dnb.d-nb.de

\section{(ㄷ) 2013 transcript Verlag, Bielefeld}

All rights reserved. No part of this book may be reprinted or reproduced or utilized in any form or by any electronic, mechanical, or other means, now known or hereafter invented, including photocopying and recording, or in any information storage or retrieval system, without permission in writing from the publisher.

Cover layout: Kordula Röckenhaus, Bielefeld

Cover illustration: jaeschko / photocase.com

Layout and Typeset by Barbara Thériault

Printed by Majuskel Medienproduktion GmbH, Wetzlar

ISBN 978-3-8376-2310-9 
à Noa Blanche 
